\title{
Ethics and Behavioural Theory: How Do Professionals Assess Their Mental Models?
}

\author{
Frank Jan de Graaf ${ }^{1,2}$ (D)
}

Received: 9 September 2016 / Accepted: 15 June 2018 / Published online: 2 July 2018

(c) The Author(s) 2018

\begin{abstract}
The role and ethics of professionals in business and economics have been questioned, especially after the financial crisis of 2008. Some suggest a reorientation using concepts such as craftsmanship. In this article, I will explore professional practices within the context of behavioural theory and business ethics. I suggest that scholars of behavioural theory need a strategy to deal with normative questions to meet their ambition of practical relevance. Evidence-based management (EBMgt), a recent behavioural approach, may assist business ethics scholars in understanding how professionals infer 'evidence' to make decisions. For a professional, ethical issues are an integral part of decision-making at critical moments. As reflective practitioners, they develop insights related to ethical concerns when collecting and assessing evidence within decision-making processes.
\end{abstract}

Keywords Professionals $\cdot$ Craftsmanship $\cdot$ Aristotle $\cdot$ Behavioural ethics $\cdot$ Behavioural theory $\cdot$ Mental models

\section{Introduction}

In recent years, professionals in the field of business and economics, especially banking and finance, have been subjected to widespread criticism. It is argued that a limited, one-dimensional approach to daily decision-making has resulted in an insufficient concern for society, the context within which professionals make decisions and the values upon which they base them (Purnell and Freeman 2012; McPherson 2013). Both finance professionals and managers (Khurana and Nohria 2008; Khurana 2010) have been depicted as only being interested in money and thus having no awareness of the ethical issues and neglecting societal interests. This one-dimensional perspective might be related to an incorrect fact-value dichotomy, as Purnell and Freeman (2012) argue: the idea that ethics can be separated from economic reasoning. However, if we refrain from separating economics and ethics, how are we then able to approach ethical issues in business and education?

Frank Jan de Graaf

f.j.de.graaf@hva.nl

1 Amsterdam University of Applied Sciences, Wibautstraat 3b, 1091 GH Amsterdam, The Netherlands

2 University of Amsterdam Business School, Amsterdam, The Netherlands
Criticism of business practices and business schools has resulted in a number of responses from professional bodies; for example, the Netherlands Institute of Chartered Accountants (NBA) and the Dutch Association of Registered Management Accountants (VRC) (NBA-VRC 2014) argued that their members need a 'moral compass'. Furthermore, a bankers' oath was introduced into Dutch banking in 2015 (see Appendix), which apparently may be necessary for managers as well, as Khurana and Nohria (2008) have argued. My analysis of recent academic insights below will show how 'training' professionals - as individuals and as members of professional associations - in the above-mentioned qualities will be a feasible proposition in the future.

In this article, I will develop a perspective on professional practices in the field of business and economics, assuming craftsmanship as a perspective in which ethics is integrated into daily action of professionals (e.g. Nielsen 2010, 2016). With the revival of virtue ethics in moral philosophy and business ethics (Fontrodona et al. 2013), craftsmanship also appears to have been rediscovered (McPherson 2013; Taylor et al. 2015). This is illustrated by the popularity of the sociologist Richard Sennett's book The Craftsman in the public domain, which depicts craftsmanship as 'an enduring, basic human impulse, the desire to do a job well for its own sake' (Sennett 2008, p. 9).

I will position craftsmanship by relating two scholarly debates. Firstly, in business ethics, craftsmanship may be 
an important concept in the discussion of moral agency, praxis and phronesis, as is currently relevant in business ethics. Secondly, craftsmanship can be related to the 'behavioural theory of the firm' - the most influential movement in management and business economics over the past 50 years (Gavetti et al. 2007). I argue that both theoretical fieldsbusiness ethics and behavioural theory-can meet in the ideas of the reflective practitioner developed by Donald Schön. To do so, scholars in business ethics and behavioural theory need to understand the role and ethics of mental models in assessing evidence.

In relating the fields, I approach ethics as entailing the examination and judging of attitudes, behaviours and practices, as well as moral judgments (e.g. Brinkmann and Henriksen 2008; Brinkmann 2009; Nielsen 2010, 2016; Fichter 2016). Within this perspective, a professional is a 'good' professional when he, as a 'craftsman', is able to reflect and act on certain virtues within his vocation (McPherson 2013). A professional is a reflective craftsman, whereas some practitioners can also be craftsman within certain definitions, but do not need reflective skills and circumstances (including training, professional standards and professional associations).

This interest in judgment, decision-making and related practices is shared by business ethics and behavioural theories. Moreover, in both, the interaction between the individual decision-making of the professional and an institutional environment - of professional associations-is seen as important.

I contribute to the business ethics literature by relating ethics to the role of evidence in decision-making and argue that this attention to evidence enables us to better understand the behaviour of professionals. In this respect, I see ethical awareness as a critical component of the 'attitude of mind, that habit of thought, which we call scientific', as Dewey states (Dewey 1910, p. 9). By relating 'habits of thought' in the spirit of John Dewey to the ethical side of mental models (Werhane 2008; Werhane et al. 2013), I argue that a professional is able to collect, assess and reflect on evidence in dialogue with (1) scientific research, (2) organisational facts, (3) stakeholder interests and (4) contextual circumstances, the four areas of evidence within Evidence-Based Management (EBMgt).

Professionals in business and economics who strive for an evidence-based approach to their work, attempting to optimally substantiate their decisions, need to understand how their behaviour is determined by the dominant mental models in their environment, the organisation they work for and the perception they have of themselves. In this regard, a systematic approach to dealing with information and reflecting on both the process and the content is essential.

To develop my argument, I start by discussing insights into professionals' behaviour within decision-making processes in organisations. Professionals have the discretion-moral agency - to make a contribution to the organisation, and thereby to society as a whole. Professionals distinguish themselves from 'practitioners through their ability to combine specific knowledge in a field-knowledge laypersons do not possess - with the appropriate attitude and behaviour (Sandberg and Tsoukas 2011; Sandberg and Pinnington 2014). They can combine knowledge in this way by reflecting on possibilities and drawing connections between technical requirements and social interests-connections that laypersons are unaware of or easily overlook. In addition to having cognitive expertise readily available, they are also able to relate this to their personal emotions and convert it into action. This allows them to develop the professional attitude that characterises professionals in business and economics capable of intellectual reflection. In addition to their competences, a level of institutionalisation of their practices-most often in professional bodies-is of relevance.

Reflection and dialogue are critical features for professionals. For these processes, training, professional associations, a code of ethics-including sanctions-and shared values are essential. This makes Khurana and Nohria (2008) argue that managers should develop these practices and standards in order to become professionals. I will not take a position in this debate about the question whether managers need professional associations and codes of ethics. However, it is clear-also for authors who criticise Khurana's ambition to professionalise managers (e.g. Barker 2010)—-that some kind of "professionalism needs to be organised to enable ethical behaviour. This does not have to imply that managers should become a part of the profession of managers. It could also imply that managers can be managers only when they are also a member of a group of professionals. For example, a manager in a bank should be a member of the profession of bankers. My reflection on Aristotle, craftsmanship and behavioural theory helps to understand the role of mental models in the behaviour of professionals.

In the next section, I start with a discussion of Aristotelian notions relating to professionals, professional associations and knowledge, which I then relate to behavioural theory by using Dewey and the notion of craftsmanship. I also address moral agency within behavioural theory.

In the subsequent section, I will address what professionals really 'do' within a developed perspective on ethics. The search for, assessment of and reflection on evidence is a critical process. In this process, the mental models of professionals take the lead, and reflection on both the processes and the mental models are critical 'actions' for a professional. Finally, I will outline a framework that combines evidence, mental models and how professionals act. 


\section{Professionals and Behavioural Theory}

\section{Practices and Praxis}

Scholars in business and organisation have an ambiguous relationship with practitioners; people whose 'work' they study, or real-life. Ever since business schools emerged in the late nineteenth century, the relationship between the work of scholars-'education and research'-and business practice has been discussed (Vermeulen 2007). Do scholars know more about practice, or do they offer a scientific - and thereby different and valuable-perspective on business practices?

Now and then, scholars have rediscovered practice: for example, the Carnegie school emerged around 1950 and behavioural theory came into existence. Around 2005, evidence-based management (Rousseau 2006) developed a similar ambition, although behavioural theory aimed to bring scientific approaches to business schools, while EBMgt promoted scientific approaches in practice.

The ancient Greeks were already ambivalent about the meaning of reality and real-life experiences. Plato can be seen as founding a tradition in which real-life experiences are distrusted. Most people live in a cave, he argued. They only see reflections of what they think is reality on a type of 'screen', but it is only a poor reflection. Only by intellectual exercise can real insight be developed, and will people be better able to see the reality of things outside the cave. For this reason, the real intellectual activities of the philosopher were considered higher than 'work'. While craftsmen were seen as important to society, the polis, and their attitude towards and concentration on daily work were seen as significant, the most important figures were the intellectuals.

Aristotle had a more empirically oriented approach than Plato. He explored how people developed insights about reality (ontology/being) — especially phenomena in natureand 'what' they could know (epistemology). In developing these ideas, the notion of real work, and in turn, the craftsman, obtained a more central position (Eikeland and Nicolini 2011; Eikeland 2012). The importance of the craftsman and the value of their attitude towards work was better recognised, although this was still not enough, according to Sennet (2008, p. 23), who questions the distinction between technology and praxis and very much emphasised the value of tacit knowledge in the application of techniques. With the use of instruments and the manipulation of materials, certain practices develop, and a lot of tacit knowledge is applied and displayed. Acknowledging the importance of tacit knowledge also means that moral agency becomes important (e.g. Painter-Morland 2006), which will be discussed further below (in the section on moral agency).
Eikeland's $(2008,2012)$ perspective on Aristotle enables us to bring together various approaches to reality. In addition to theory, there are various other ways of knowing. In using instruments and the manipulation of materials we develop insights, khresis and poiesis, respectively. With respect to manipulation, 'techne' (technical rationality) is a critical form of understanding. This would suggest that technical rationality is necessary for using instruments (khresis) and manipulation of material (poiesis). This rationality is different from praxis, in which 'phronesis', forms of wisdom, is critical. As such, praxis can be divided into (1) phronesis, a form of rationality in which reflection is key, and (2) dialectics, certain 'training' relational and development-oriented processes. This implies that practices and 'praxis' are different. In short, practices become praxis when phronesis and dialectics are needed (see Eikeland 2012).

In his argument for craftsmanship, Sennett (2008) does not see 'techne' and 'phronesis' as separate in every situation. At critical moments, a 'real' craftsman knows that technical rationality is not enough and has to build on phronesis. The ability to use phronesis next to technical skills and knowledge distinguishes a craftsman from a practitioner. According to Sennett (2013), too often 'technology' is seen as independent of wisdom. Even in some management practices, a technical approach seems at times to be dominant, whereas in management practices, phronesis is at least as important as technical rationality.

The interrelationship between various forms of knowledge is complex. To apply various insights, Aristotle stresses the importance of dialogue. Here, he tends to use the related word 'dialectics', because he wants to distinguish the nature of this process from dialogue in which rhetorics-as taught by sophists-is prominent (e.g. Eikeland 2008, p. 218 e.v.). Aristotle admits that rhetorics are important, but they have to be confronted with ways of knowing, and a certain dialectic between 'rhetorics' and between various forms of knowledge is necessary. For these processes of dialogue, he starts to develop certain methodologies: particular steps to detect what is of value in a given situation. Dialectics is also critical in the use of theory (Eikeland 2012, p. 20).

Eikeland's use of Aristotelian notions can also help us to understand professionals and professional bodies. Professional bodies represent the relational aspect of praxis, focusing on standard-setting and training. In relation to 'phronesis'-including ethical considerations-we can understand the professional as an individual, a person who is able to do something and as someone who is able to reflect on their practices and thereby continuously improve their abilities. Thus, reflection is a critical component of the work of professionals.

Eikeland and Nicoline (2011) also discuss ways of knowing in daily action. The use of instruments and the manipulation of materials is more 'technical', as we tend to say 
today. Using a similar logic, we might say that a dentist is more technically oriented and an IT engineer more 'technical' than a manager. These distinctions also help to pinpoint when and where ethical issues might arise and why certain technicians never become aware of the ethical issues in their work.

This perspective makes ethics an integral part of judgment and leadership (Giessner and Quaquebeke 2010; Shotter and Tsoukas 2014), while an exploration of praxis helps to further understand the concept of being a professional and why they are 'professionals', combining deliberation with techniques and constant dialogue with fellow professionals. As professionals, they have moral agency or-as managers-discretion. To enable this, dialogue mechanisms have often become institutionalised. For example, most professions have permanent education programmes, a register, a code of conduct and a disciplinary board. Here Khuruna and Nohria (2008; see also Khuruna 2010) conclude that managers lack a professional orientation. Also, it becomes clear that professional practices can include both praxis and techne that these concepts can become entangled and that some practitioners present practical solutions as technical solutions, thereby neglecting critical ethical questions.

\section{Decision-Making}

Decision-making is a critical unit of analysis in business ethics (Martin and Parmar 2012; Bazerman and Gino 2010; Fichter 2016). In order to determine how professionals should perform in daily practice or, in other words, how they should deal with moral agency, we must establish what this practice comprises. Behavioural theory of the firm has played a dominant role in business economics and management in the past 50 years. It is a collection of theoretical insights that place the decision-making process at centre stage.

In this body of theory, decision-making processes are viewed as "the quasi resolution of conflict, uncertainty avoidance, problemistic search and organisational learning [which] are central phenomena with which our models must deal' (Cyert and March 1963, p. 123). They are processes in which those involved endeavour to avoid conflict and insecurity based on a fumbling search. When designing organisations, we need to take account of the complex decisionmaking processes. Only a limited number of decisions are made by people who understand the full picture, who are absolute experts.

It has resulted in several movements, including behavioural economics, which focuses on cognitive models-put simply, the perceptions and structures in people's minds-in order to understand how decisions are made and to make recommendations to improve decision-making. A behavioural perspective is relative new in business ethics (Treviño et al.
2006). A behavioural approach to business ethics examines how individuals make ethical decisions and judge the decisions of others. As such, decisions that are at odds with intuition and the benefits of society at large are of specific interest (Bazerman and Gino 2012).

Behavioural theory of the firm indicates that people very often fall back on routine or habits in their daily activities. Conscious decisions are made every now and again, but even then, people are influenced by motives of which they themselves are often unaware. In our daily lives, we make decisions based on incomplete information, and our emotions are often much more dominant than our power of reason (Kahneman 2002). We allow ourselves to be influenced by an entire range of unconscious motives. Often people make decisions in a complicated and diffuse reality in which information is incomplete, facts are contradictory, political concerns are of major importance, and where there are often insufficient resources to reach a truly well-considered decision.

In the tradition of behavioural theory, a wealth of research has been conducted into decision-making processes since the 1950s. Social psychologists, in particular, have discovered through experimentation that we face numerous pitfalls when making decisions. For example, we make assessments based on various numbers we have in our heads at the time, irrespective of whether the numbers are relevant to the product. A well-known example is when a supermarket product is priced at $€ 3.99$, we tend to perceive that it costs a little more than $€ 3$, when it actually costs $€ 4$. Here, behavioural theory refers to biases (assumptions that are applied without fail) and heuristics - the application of assumptions in practice (see Tversky and Kahneman 1974) (Table 1).

From a perspective of a professional, social psychological insights have an important limitation. They are strongly descriptive and thereby give little guidance on how a decision-maker should avoid these biases in their assessment (Sonenshein 2007; Fichter 2016). Reflection is seen as a critical mechanism here (e.g. Ariely 2009).

\section{John Dewey and Moral Agency}

Because behavioural ethics is also strongly descriptive (Bazerman and Gino 2010), it offers little insight into what is 'good'. Social processes seem to be the most influential factors here. Certain issues and developments are 'good' only within the perspective of decision-makers and their stakeholders. Another implication of this descriptive character is that it gives little conceptual guidance for relating the work of professionals to ethics and craftsmanship.

This is related and ties behavioural theory to Dewey's philosophy of pragmatism (Cohen 2007a), or, more specifically, his epistemology. Dewey argued that in order to understand reality we should begin by examining what people 
Table 1 Example of three accepted heuristics from social psychology

\begin{tabular}{|c|c|c|}
\hline Heuristic & Description & Example \\
\hline Availability heuristic & $\begin{array}{l}\text { The chance of something happening is dependent on } \\
\text { whether it is easily conceivable }\end{array}$ & $\begin{array}{l}\text { The risk of an accident is perceived to be higher if an } \\
\text { accident has recently occurred }\end{array}$ \\
\hline Representative heuristic & $\begin{array}{l}\text { The inclination to arrange everything into categories before } \\
\text { subsequently assessing them, irrespective of whether the } \\
\text { categorisation is correct }\end{array}$ & $\begin{array}{l}\text { You perceive companies with blue logos to be reliable, } \\
\text { because you have had positive experiences with } \\
\text { companies with blue logos in the past }\end{array}$ \\
\hline Anchoring heuristic & $\begin{array}{l}\text { An assessment that depends on a random idea or number } \\
\text { seen at an earlier time }\end{array}$ & $\begin{array}{l}\text { If you have just purchased a product costing } € 10 \text {, a } \\
\text { moment later a product costing } € 3 \text { seems cheap }\end{array}$ \\
\hline
\end{tabular}

actually do on a daily basis rather than by defining a theory. He proposed that people connect cognitive processes, emotions and intuition (head, heart and hands) when they act, and that if we can discover how they do this, we can help them to solve their problems more effectively.

A core idea behind pragmatism is that people are not able to solve their problems by thinking (cognition) alone-moral agency is also required. Cognition has critical limits; emotions and habits heavily dominate our behaviour. In the complex situations, we all encounter on a daily basis, people make the majority of their decisions based on 'habits'-for example, getting up in the morning and driving or travelling to work by a certain means. Habits are also crucial once we arrive at work. These routines combine certain knowledge with cognitive models, which can be developed further if more knowledge is acquired. Emotions make an important contribution and also act as a warning signal. People need to be able to understand the importance of knowledge and appreciate the importance of learning new ways of acting.

The 'head, heart and hands' triad has influenced education in the United States since the 1930s (e.g. Ruhe and Nahser 2001). It is recognised that simply passing on knowledge is not sufficient. People also need to gain practical experience by doing, which directly relates to craftsmanship (McPherson 2013; Taylor et al. 2015). Here the normative component of craftsmanship comes in. The craftsman does 'good' work according to their own professional judgment, and thereby contributing to society at large (Sennet 2008). When we go back to the roots of behavioural theory, the actionoriented and relational epistemology of John Dewey offers some ground on which to relate craftsmanship to ethics and decision-making processes. Sennet (2008, p. 287) relateswith reference to Dewey-the spirit of craftsmanship to the 'animal laborans', the idea that humans can be enriched by working, that action and learning are intertwined.

In On Valuation, Dewey (1939) defines his ethical position in between on one side, values are emotional as epithets and, on the other side, values are a priori standardized. Valuation is an interpersonal activity in which values are at the nature of propositions that require interpersonal activity. According to Dewey, it is about liking and disliking and in these processes conditions are critical. Within the right conditions, the right values can develop-in this last statement the educator becomes visible. Inter-personality does not consist out of 'talking' only, but has to be an experience rooted in the real world, is only possible when people are working together.

Dewey (1910) argued that students should prepare for daily professional life through appropriate education combining knowledge and 'skills' - 'activity-related' knowledge. He claimed that knowledge, skills and competences are all linked, in both the educational and professional spheres. This also applies to the behavioural theory of the firm. Research focuses on the practical side of decision-making, and the fact that this is an area where various interests and perspectives meet. The emphasis on education and skills is important to Dewey because people have freedom of choice, no matter what system they are part of. Again, here moral agency comes in. All people are co-creators of their own environment and certainly are professionals in modern knowledge-driven organisations. This often leads to a feeling of chaos and insecurity, but also characterises the value added by highly educated professionals.

Only a limited amount of the work conducted by professionals consists of repetitive actions in accordance with strict protocols, and every day entails making a huge variety of different decisions. Even work that is heavily 'protocolled' and limited to a specific area of expertise-such as dentistry-involves a wide range of individual assessments. It is these assessments that are of crucial importance, as they help to distinguish between effective and less effective professionals. But how should we envisage this freedom of choice? How should we deal with moral agency?

\section{Moral Agency and Managerial Discretion}

A significant guiding principle of behavioural theory is that people can decide how to structure their work and private lives themselves, although they are nonetheless subject to group influences and have difficulty making sensible decisions. Although group pressures exist, students, employees and managers all have certain forms of 'discretion' at their disposal, in the sense of having scope to make their own choices and handle 'things' their own way. This 
is what management theory refers to as managerial discretion, while ethics scholars use the term moral agency. For professionals, discretion and agency have an additional dimension. Professionals not only have a relationship with, or are agents of, their organisation, they are also agents of their profession, most often represented by a professional association (Khurana 2010).

In understanding moral agency in professional behaviour, a behavioural perspective on decision-making and ethics has its limits. Behavioural theorists assume that the quality of ethical decisions is related to the judgment of the decisions of others. In this respect, 'the decisions that are at odds with intuition and the benefits of the society at large are of specific interest' (Bazerman and Gino 2012 , p. 2). In line with Dewey, the quality of a decision is related to the benefits of society in general. However, where Dewey had a clear and specific (socialist) perspective on society, behavioural theory does not give any guidance here. Without ethical guidance, managerial and professional discretion becomes more problematic. So, what is a 'good' decision? Some blame William James's exclusive interest in 'the thing which works' for the ethical blindness of pragmatists and many research areas in the US (e.g. Ruhe and Nahser 2001). Dewey followed James in many respects.

Before we discuss an approach that can reinforce ethics in behavioural theory, we must first understand what behavioural theory teaches us about the nature of a 'good' decision in relation to moral agency. As mentioned above, people only make limited rational use of this discretionary scope. This is known as bounded rationality. People are heavily influenced by the perceptions they have of themselves, the contexts within which they work (organisations) and their environments. A bothersome consequence of this is that human behaviour can only be charted in rules and procedures up to a certain point, because people are often not aware of the motives that dominate their behaviour. This means that they have problems, for example, following regulations and protocols. Not only are some activities difficult to encompass in protocols (e.g. creative design processes) but, even more problematic, humans are only able to remember and work in accordance with a very limited range of rules.

Behavioural theory of the firm essentially deals with two different schools of thought concerning the extent to which we can influence the limits of human rationality. The two approaches can often be traced back to insights regarding the autonomy of the decision-maker. While in-depth debate on the matter is yet to be conducted, Cyert and March emphasise different elements to Herbert Simon (Cohen 2007b). The former place more emphasis on the complexity, historical definiteness and ambiguity of decision-making, while the latter suggests that cognitive models can make this complexity and ambiguity significantly more manageable.
Simon reasons that by following appropriate models we can overcome many human limitations.

The two schools of thought in behavioural theory can also be traced back further to a different interpretation by Dewey. Where Simon separates the head (cognition), heart (emotion) and hands (routines), Dewey views them as being integrally linked in a 'dynamic interplay' (Cohen 2007a, p. 777). They also differ in terms of terminology. Dewey referred to 'habits' and Simon to 'routines'. The latter is much more closely linked to standardised activities, such as those carried out by workers on a production line.

Both stances-Simon's 'predictable irrationality' and Cyert and March's 'unsolvable ambiguity'-have their own paradoxical element concerning managerial discretion. In cases where decision-making is by definition ambiguous and complex, there is not much we can say on the matter. Where it can proceed according to a model, individual responsibility ceases to exist and humans are reduced to little more than computers. Both movements agree that the type of education decision-makers receive is crucial. They must be able to (1) design suitable decision-making models or (2) attach meaning to the right elements in a complex world. Here, the relational aspect comes in, and thereby moral agency. Relational systems - technical or not-should help the decision-maker to make the best possible decision.

The implicit split between Simon and March can also be found in current scientific research. 'Institutional' thinkers (e.g. DiMaggio and Powell 1983; Granovetter 1985) draw attention to institutional and social processes which give meaning to some ideas and exclude other. In this respect, they follow March. These theorists have strongly influenced theories of practice (e.g. Sandberg and Pinnington 2009), assuming 'praxis' to be a core mediating mechanism of institutional change (Seo and Creed 2002). They share Weick's (1995, 2016) focus on real-life stories from professionals' companies and attempt to interpret these in their research.

A large group of primarily social psychologists shift the emphasis entirely and emphasise Simon's orientation. For example, Daniel Kahneman's (2002) research focuses on uncovering unequivocal rules of behaviour-the heuristics mentioned earlier. This is also reflected in his renowned model-based scientific approach, using experiments in a controlled, laboratory-esque environment. Interestingly, research such as that executed by Kahneman on heuristicsas has been described above-show that this approach does not work in practice.

Taylor et al. (2015) suggest that this divide is related to two perspectives on management and decision-making. Where some, for example Mintzberg (2004), define management within a conjunction of science, art and craft, others suggest that management is a science only. Mintzberg is more in line with March (see for example 1987), while Simon emphasises a scientific ambition that is comparable 
with the natural sciences. In Taylor et al.'s analyses, the craft of management has important normative foundations, where a limited science only perspective tends to underestimate normative assumptions. Taylor's idea is more in line with Dewey's, in which science is not limited to cognitive understanding but leads to 'skilled' experience (in action). In this respect, it is also in line with Sennett's (2008) and Eikeland's (2008) perspective on practices.

Efforts are currently being made to unite the two schools of thought, in both research and higher education. Cohen (2007a) argued that behavioural theory places too much emphasis on cognitive processes, while from the outset, Dewey and other founding thinkers also attached great importance to normative and relational processes-emotions are significant in both. It is important for decision-makers to not only possess specialist professional knowledge but to also place it in a broader social framework in order to be able to reflect on their professional practice (Sandberg and Tsoukas 2011; Sandberg and Pinnington 2009). The liberal arts are also very important for individuals to be able to develop a suitable philosophical framework within and on which intellectual reflection is possible (Nussbaum 2010), including subjects such as languages, history, anthropology and psychology. Attempts are being made to unite these elements in the educational sphere within the triad of 'head, heart and hands'. Professionals need to be adept at thinking and connecting with emotional needs (such as the need to be part of a community and shared norms), and only then will people be stirred into action.

Within this perspective on decision-making, moral agency and managerial discretion are both elements of phronesis (Shotter and Tsoukas 2014). Facts and values meet in this realm in which tacit knowledge is prominent (e.g. Painter-Morland 2006). Where traditional views on moral agency and the professional suggest that they are able to assess a case based on their own experience and according to the standards of their profession, 'recently', rediscovering Aristotle, professional identity has been seen as relational, which fits very well into Dewey's understanding of reality. A professional is not a content-related specialist who assesses a situation, making a judgment that is in line-or not—with their personal values. In a given context, professionals make decisions that are related to the person they are, their professional standards and the context in which they work. This makes professional identity relational and fragile (Thomson and Jones 2016) and often developed through informal, tacit, professional 'codes of ethics' (Painter-Morland 2006).

From this perspective, rational and moral agents are replaced by individuals who operate in organisational and institutional contexts that strongly determine their agency: their ability to make their 'own' decisions. Professional identity and individual identity are intertwined with each other and with perceptions in the context within which the professional operates. Within this constellation, a professional is capable of acting with reference to right or wrong in relationship to their professional standards. This makes a professional a specific kind of moral agent.

\section{Reflective Practitioner}

Because moral agency issues are part of the work of professionals, because they have to choose between a variety of models, systems, rules and protocols during their work, a suitable professional attitude and behaviour is necessary (Nielsen 2016, p. 421). In his book, The Reflective Practitioner, Schön (1983) describes this required attitude and behaviour. Without making a clear distinction between practitioners and professionals, he focuses on the issue of how professionals deal with professional standards and with the expectations and complexities of their environment, referring to Dewey's Theory of Inquiry (see also Schön 1995). In his analysis of a range of professions, he demonstrates how professionals reach decisions in constant interaction with their environment. They are not only guided by their own knowledge, but listen closely to their environment and adjust their actions accordingly.

Following Schein (1973), Schön simplified Aristotle's onto-epistemology by arguing that the knowledge of professionals consists of three components (see also Argyris and Schön 1974). A professional can call on (1) basic science or scientific knowledge, (2) applied science (scientific knowledge used in practice) and (3) competences and a professional attitude. Expertise, therefore, is the sum of these three areas combined.

Schön (1983) argues that both academics and professionals are often inclined to pay too much attention to basic science, overlooking the relationship with the other two areas. Here, he criticises Simon, including important traditions within behavioural theory (Schön 1983, p. 46-49). Implicit in his suggestion is the notion that professionals are all-knowing in their area of expertise. This does not match the situation in practice where, since the nineteenth century, the medical sciences have served as a role model for numerous other professions. Physicians possess fundamental knowledge of the human body, know how to repair it and have the appropriate skills and professional attitude (e.g. conducting intake consultations and taking a professional oath). The lack of clarity regarding the relationship between these areas of knowledge is even more pronounced in some professions because the basic science upon which the profession is founded is unclear.

Three decades later, and based on the ideas of European philosophers such as Pierre Bourdieu and Anthony Giddens, practice theory developed a comparable approach, which considers that the structural conditions of social life develop 
through everyday action. This implies that individuals work together to develop the environment in which they operate, and it is not possible to make a clear distinction between the individual and the environment in which they operate (Feldman and Worline 2016, p. 320).

The knowledge of a reflective practitioner or professional is not static, but constantly shifting, with a large variety in form and orientation. For example, it can be focused on theory, the use of instruments or be related to praxis, insight (phronesis) or dialogue (Eikeland 2012). In both phronesis and dialectics, ethical considerations are part of any judgment. In any case, economics, psychology, sociology, anthropology and mathematics all play a role in business management and economics, but concerns such as ethics and history also sometimes require attention. Professionals looking to learn how to contend with this dynamic need to gain insight into the complexity and dynamics of the organisations in which they work and the environment within which the organisation operates.

Social psychologists (e.g. Weick 2016), behavioural social psychologists (e.g. Kahneman 2002), behavioural economists (e.g. Ariely 2009) and more sociologically sensitive theorists such as Schön (1983) and Shotter and Tsoukas (2014) all argue that intellectual reflection ultimately plays a crucial role in making the best possible decisions. If professionals are able to reflect on their own personal and professional values, their organisation's values and values in the wider environment, we can create a framework of norms that fits a specific situation. Ethical concerns also need to be taken into consideration, due to the fact that research is transactional, open-ended and inherently social (Schön 1995, p. 122; see also Feldman and Worline 2016; Weick 2016). Therefore, there is only a limited difference between scientific research and common sense because, following Dewey's reasoning, scientific research begins and ends with common sense. Dewey only permits himself a severely limited amount of reflection on the nature of ethical norms and potential conflicts between ethical points of departure.

This makes intellectual reflection vital for the associative and integrational capacities of the professional (Shotter and Tsoukas 2014). By distancing themselves from the immediate reality, professionals can learn to link diverse facts, opinions and perspectives (Gavetti 2012). When doing so, insight into personal norms as well as norms at the institutional (mental models) and organisational level is crucial (Simon 1965). Only once decision-makers are aware of the field of influence in which they operate will they be able to adopt a certain cognitive distance, make decisions that are innovative and further develop the rules of the game, without losing contact with their environment.

Reflection is needed to bring professionals' behaviour and actions in line with the expectations of their environment (Rousseau 2006; Nielsen 2010, 2016; Fichter 2016).
For example, in the case of external auditors, it is not only important to make sound decisions for themselves and their direct clients, but also that these decisions are in line with the expectations of their environment and society as a whole. Accountants audit figures not only for a company itself, but also serve the particular interests of shareholders, suppliers and clients who need to understand the company's state of financial health. With respect to this variety of interests, a certain order is necessary to make an individual decision. Sometimes the interests of employees are more important than the interests of shareholders, or vice versa. In relation to this decision, certain guidelines are necessary; a certain idea about what counts in reality.

\section{Mental Models}

Reflection processes in a complex and diffuse environment are related to the perceptions of organisations, the environment and the own role of the professional (e.g. Gavetti et al. 2007; Werhane 2008; Werhane et al. 2013). The human mind organises and orders its experiences based on earlier experiences. These earlier experiences profoundly interact with current experiences, which leads to a 'new' model of reality. In approaches to organisations discussed above, these processes of social construction are critical (Werhane et al. 2013). Aristotle was already aware that practical knowledge demands 'rational fictions'; pictures of reality that are both rational and appeal to the imagination (Flyvbjerg 2001).

The following example illustrates this process: people allow their behaviour to be influenced by images they see of a fashion brand or a supermarket, for example. In this case, it is inconceivable that a supermarket offering a huge selection in a store with immense visual appeal could be as cheap as a supermarket offering a small selection in an empty store filled with boxes. If these perceptions fail to add up, people become confused and they have to assign new meaning to their environment. This example raises the question of how individuals ascribe meaning to facts and how the environment in which they work influences this process. On this point, certain scholars (e.g. Gavetti et al. 2007; Gavetti 2012; Martin and Parmer 2012; Bagdasarov et al. 2016) concur with notions introduced by Karl Weick (1995) regarding 'sensemaking', or the ascription of meaning. In the words of Shotter and Tsoukas (2014), this is related to phronesis, a hermeneutic development process in which moral agency, language, usage and emotions are far too easily ignored, and reflection and other ontological skills are necessary to deal with perceptions and virtues.

The determining role of mental models corresponds with Simon's argument that individuals are often unconsciously influenced in their decisions by models at the institutional, organisational and individual levels (Koumakhov 2009, 
2014). Individuals have certain expectations of the environment (how things happen), of an organisation's purpose and of an individual's objective. Decision-makers have, for example, expectations regarding markets, competition, how the organisation should look in 10 years' time and where they themselves want to be.

Often, these expectations are implicit; they are sometimes made explicit in financial models, but also in exemplary behaviour, accounting regulations and codes of conduct. These models are normatively charged, that is, to a large extent they establish human behaviour. Nevertheless, as stated above, every decision-making process always features an element of discretion-scope for individuals to emphasise certain elements and, in some cases, to gain complete control of the decision-making process. People make their own decisions through interaction with their environment, with colleagues and competitors, but also with market models. Within these interrelations ethics develops. Once we become aware of how our actions are influenced by certain models, we can determine how we could arrive at other models. But we can only do this once we are aware of the value judgements underlying the models we use, which makes a certain amount of insight into ethics important (e.g. Bowen 2007; Purnell and Freeman 2012).

The dominance of mental models can explain why 'good' decision-making processes do not automatically lead to 'good' decisions. Both the process and the decision reflect moral values, an issue which tends to be under-estimated in Dewey's pragmatism (e.g. MacIntyre 1985; Bernstein 1971, 2013).

The evidence-based approach of behavioural theory of the firm therefore gains a moral dimension (see also Bowen 2007). Whereas this body of theory is inclined to place its faith in good processes and to assume that norms and values will develop of their own accord, it is now becoming clear that there are a range of basic normative principles that heavily influence professionals' relationship with reality.

These normative principles are reflected in the objects the craftsman works with. Such 'artefacts' (Simon 1996) can be decisive in the decision-making process. Simon (1996, p. 5) defines artefacts as 'models' and 'tools' which synthesise certain experiences in a process of dialogue by which these experiences are related to the natural world in which the participants want to achieve social goals. Scientific knowledge is not the only information relevant here, but also applied science and contextual knowledge of the practitioner (Schön 1983; Nielsen 2016).

\section{EBMgt}

In the last decade, a behavioural perspective on practice has been further developed by research on evidencebased management (EBMgt) theory. EBMgt seeks to assist professionals-framed as managers-in making wellfounded assessments that take account of social factors and ethics. It aims to promote a scientific approach to using information in practice (Briner et al. 2009). In practice, decisions are still all too often based purely on something feeling right, despite the fact that scientific knowledge and methods can significantly improve decision-making processes. EBMgt argues that practitioners should learn to connect (1) scientific theory, (2) insights offered by professionals from the organisation and (3) stakeholders' ideas to (4) the context of the organisation in a responsible manner. Scientific methods can assist in combining and applying these various forms of knowledge. Practitioners should thus assess evidence based on methodological fit, transparency, consensus, replicability and contextualisation (e.g. Briner et al. 2009; Baba and HakemZadeh 2012). In accordance with EBMgt, it is key is that academics should help practitioners in making 'good' decisions. With this perspective, beginning with Simon in the 1950s and Schön in the 1980s, attention to decision-making in practice once again gained traction in academia.

However, until now, EBMgt has paid-in line with behavioural theory-little attention to the role of norms and, related to this, power, as displayed in the position that a person has (Hornung 2014). Theorists do not take into account the difference between the a practitioner and a professional. The focus has primarily been on the decision-making process itself. Nevertheless, it is very clear that EBMgt has a relational perspective on norms, and thereby it is in line with Dewey's pragmatism and the relational and stakeholder perspectives on business ethics that have developed.

The assumption behind EBMgt is that the closer the various producers and users of evidence work together, the greater the chance of increasing the quality of decisions (Baba and HakemZadeh 2012, p. 847). This also has consequences for information regarding the role of the environment in EBMgt and how those involved deal with this information. Rousseau (2006), for example, argues that the ability to combine various types of information demands meta-skills, which brings us back to the above-mentioned insights that are crucial for professionals; namely, reflecting on knowledge about what takes place in the institutional environment and how this influences the daily operations of an organisation. However, EBMgt helps us to understand that professionals need to deal with information effectively and methodically in order to be able to make good decisions.

The previous section addressed the notion that in order for professionals to make good decisions they need to be able to reflect on the field of influence in which they operate and put their own mental models up for critical discussion. EBMgt can help them to reflect on the evidence they construct. The issue of applying appropriate ethical values is important from this perspective, which is related to the social context 
within which a decision is made. Professionals need to be able to investigate both their own judgements and those of others, and must make choices. Professional bodies ensure that judgment goes further than common sense. EBMgt offers several forms of assistance in developing evidence. If we put EBMgt within the perspective of the reflective practitioner, a professional, a fruitful perspective develops. EBMgt can be related to ethical norms, with both ethics and EBMgt having a visible impact on daily decision-making.

Within the behavioural theory perspective outlined above, the advocates of EBMgt can be split into two groups. One group argues that science will find the only correct answer using the correct question, the correct method and the correct data. This corresponds with Simon's proposition that models can minimise the limitations of rationality. Another group, more closely allied with Cyert and March, argues that in a critical analysis, differences in power, and the importance of the context and values should always be considered, and that this ultimately determines the quality of decisionmaking (e.g. Hornung 2012; Hodgkinson 2012).

This then takes us back to the importance of education and the role of norms and values therein-a crucial question affecting the structuring of education and research within business economics and management in the coming years. Further investigation into the relationship between behavioural theory of the firm and EBMgt—-looking beyond Simon-can help establish what form these meta skills (Rousseau 2006), such as reflection, contextual awareness and investigative capacity, could take and how various forms of substantiation or assessment could be combined.

This will also allow scholars to link the two dominant movements within behavioural theory of the firm: the 'model-based approach' adopted by thinkers such as Simon and Kahneman, and the interpretative and contextual approach of others such as Granovetter and Weick. The model-based approach clarifies the importance of procedures and rules - related to corporate governance- that determine the behaviour of professionals, while institutional thinkers and psychologists such as Weick $(1995,2016)$ highlight the importance of offering meaning and leadership within these rules and processes.

Alongside scientific perspectives, the normative opinions of stakeholders also play an important role here. These can often be traced back to habits and routines. For example, stakeholders have certain opinions regarding their own role and responsibilities, how their sector operates within society and their organisation's unique character. Simon (1965) refers to (1) opinion of role, (2) mental models of the social context and (3) perceptions of and extent of identification with an organisation (see also Koumakhov 2009, 2014).

These models that professionals (often unconsciously and routinely) employ can be related to EBMgt, allowing us to gain insight into how professionals substantiate decisions and upon what basis (decisions on the measures of proof).

\section{Discussion}

The above suggests that EBMgt can help business ethics to understand the process of 'fact construction' by professionals within institutional structures, procedures and processes. The insights on professionals given by Aristotle and the behavioural perspective rooted in American pragmatism find each other in their attention for virtues, but they emphasise different aspects of decision-making. Where Aristotle tends to emphasise the relation between virtue and contemplation, Dewey puts more emphasis on action (Pagan 2008). Within the perspective on professionals as presented in this article, contemplation and action are interrelated.

Business ethics can help to develop the stakeholder perspective of EBMgt and clarify when ethical questions must be addressed. In this respect, it may assist EBMgt scholars in achieving their ambition of bringing together scientific methods and business practitioners. To do this, EBMgt seemingly needs to determine the stage in which ethical deliberation should take place. Most often, 'the facts' will not tell us the 'truth'. Not only because behavioural theory teaches that people are not able to completely understand reality. More important is that mental models play a dominant role in the construction of facts, as is suggested by both Kahneman (2002) and Weick (1995, 2016). Although both are labelled social psychologists, they have a radically different viewpoint to the onto-epistemologically perspective. When EBMgt suggests that finding the right approach will lead to scientific answers that are unquestionable, it suffers from a functional fallacy (e.g. Hornung 2012; Hodgkinsson 2012). When EBMgt is seen as functionalist, the embodied, habitual and tacit dimension of craftsmanship is lost, and, as such, the value of Dewey's insights and relevance to professional practices will be undermined.

Our craftsmanship perspective also suggests a relevant point of interest for business ethics. The development of evidence in practice is critical to understanding moral agency. This can be related to the insights of Aristotle and Dewey. Their theories allow us to realise that when business ethics tend towards a purely philosophical and theoretical point of view, ethics may be engulfed by theory. When business ethics sometimes appear to favour 'contemplation'-following Aristotle-behavioural theory is action oriented. Here, the latter offers a number of insights into the fuzzy processes that professionals have to act in, for example the role of heuristics and biases. In his time, Aristotle already struggled with the nature of dialectical processes in practices (Eikeland 2008, p. 224-225). 
Where some criticise scholars in business ethics for overvaluing theoretical and conceptual research (e.g. De Cremer et. al. 2010), behavioural approaches such as EBMgt face a comparable temptation. It can lead to technical exercises only, suggesting that it is easy to apply scientific methods to practical problems. Whenever it turns into pure technique and becomes deterministic, critical ways of knowing in practice disappear, and consequently professional behaviour disappears. Aritstotle's perspective on knowing keeps on reminding us that various perspectives are needed and should be further developed. Within this perspective, the work of Schön (1983) can be inspirational for researchers in business ethics and EBMgt.

Table 2 relates Simon's propositions regarding conventions and routines in decision-making to EBMgt and professional competences. He argues that implicit opinions regarding (1) the role of an individual decision-maker, (2) the organisation and (3) mental models such as those reflected in sector standards and society (i.e. institutional values) are determinate factors in decision-making (Koumakhov 2009, 2014). These can be viewed as alternative classifications of organisational objectives and stakeholder values - two fields of evidence in EBMgt.

This classification illuminates the influence of normative judgements on forms of evidence in academia and among stakeholders. Decision-makers tend to allow their own opinion of their role to interfere with how they assess external information (e.g. whether it presents a threat to them). If they are also required to relate this information to opinions of their colleagues and stakeholders, their decision will be influenced by social and sector standards to a large extent, and assessed in relation to these standards. Decision-makers need to work together to reach a consensus on what is important and to what extent. Alongside discussions of individual opinions, organisational objectives and uses in a sector are important (both are often seen as codes). This process improves when there is a large degree of transparency, which increases the confidence of those involved.

All parties to a decision-making process are also involved to a certain extent with the organisation in question and identify with that organisation to a lesser or greater degree. Simon terms this 'social and organisational identification', which determines how those involved assess information in context, what they consider relevant, and what not.

Put simply, Simon demonstrates that decision-makers first need to carefully define their own normative opinions regarding (1) their role and what they think about it, (2) their sector and wider society and (3) the role of their organisation therein. This is illustrated in Column 2 and can be revealed by the organisation's vision or mission, for example. Based on this normative starting point, it is possible to assess which information is relevant to substantiate a decision.
Column 3 presents the preconditions for 'good' information or evidence upon which a decision can ultimately be based. Properly formulating a question and linking a relevant methodology to answer it are important for sound substantiation. This should correspond with practices in the discipline in question and societal expectations, and be related to the organisation's objectives. Here, transparency and replicability-also presented in Column 3-are important in order to assess a decision's validity and reliability.

The areas of knowledge outlined in Column 4 are important for proper substantiation. They are linked to decisionmakers' conscious and unconscious perceptions of their role, the organisation and society (Column 2).

The model presented is complex. On every level, a variety of mental models are able to develop, models that are usually partly tacit. Even if people could, it would be exhausting to discuss every mental model in a certain situation. In addition, a constant discussion about mental models on various levels suggests a more interpretive approach. This approach is often questioned by Simon; for example, when he questioned 'Gestalt' approaches in science. He has strongly emphasised the role of verification and replicability as cornerstones of the sciences. In this regard, the tension related to bringing the various perspectives on knowledge into one perspective, as Eikeland $(2008,2012)$ suggests, is in line with Bernstein $(1971,2013)$.

Although the model in Table 2 is complex and needs further development, it could be of value for approaching ethical issues in business and education. For example, in business ethics classes, it could help to question dominant mental models at an individual, organisational and institutional level and relate these levels to various areas of knowledge in EBMgt.

In the above, I have attempted to relate behavioural approaches to normative and interpretive approaches, arguing that both are relational and reflective. However, if a similar normative appreciation of craftsmanship, professionals and evidence does not develop in the various fields, the individual theoretical preferences of scholars will hinder the development of academic work that is relevant to business and society, now and in the future.

Subsequent research should focus on the role of intellectual reflection in education and research and the role of ethical and other assumptions, as also proposed by Dewey and Nussbaum. The paper demonstrates that the development and role of reflection is related to the question whether managers are, or should be(come) professionals (e.g. Khurana 2010; Barker 2010). The processes in which reflection takes place is especially relevant. More insight is required into how mental models change and the role of institutional relationships in this matter. For example, to what extent is change in the financial sector stymied by particular models employed by decision-makers in a sector. This may be of 


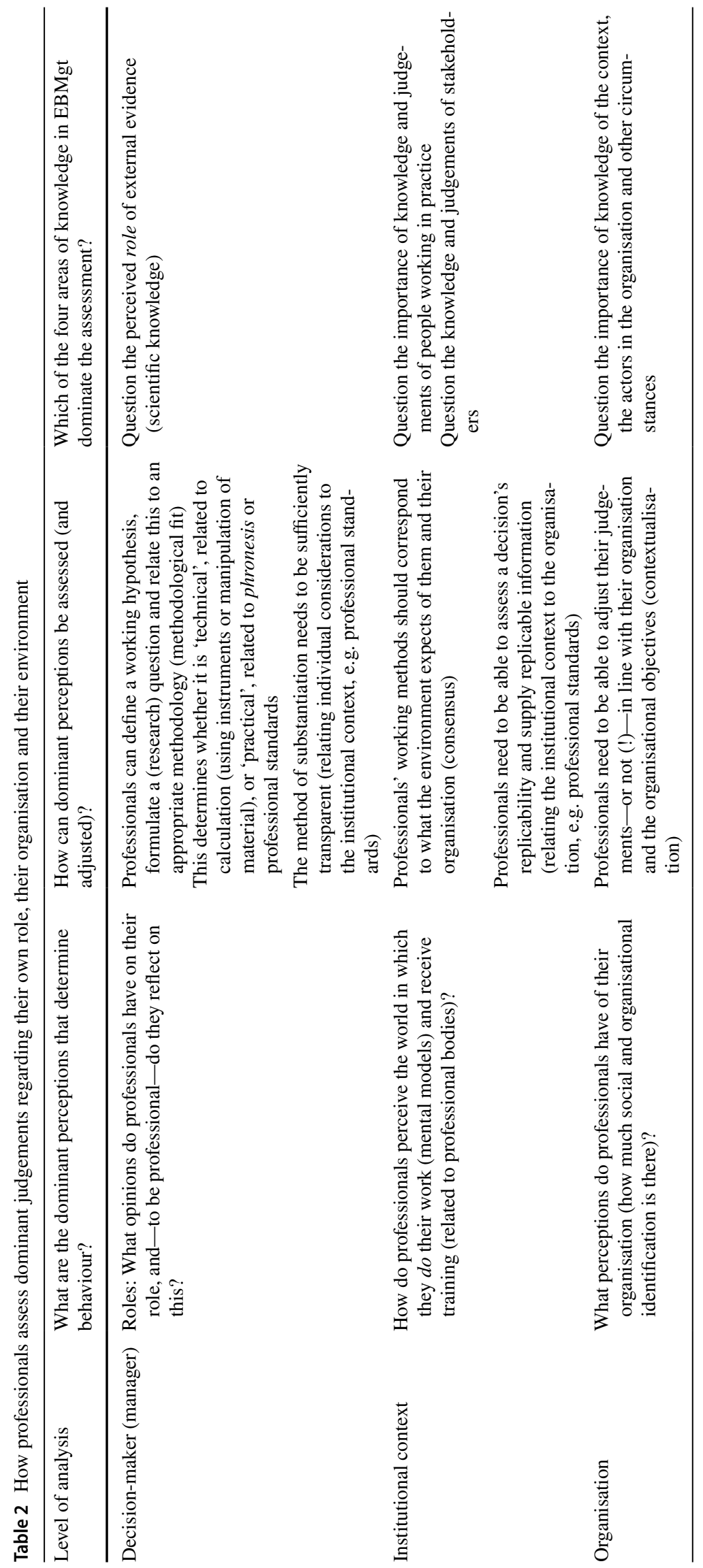


even greater importance for business economics in light of the extreme forms of codification seen in the monetary system and associated banks, investors and insurers.

Within the study of these processes, behavioural research should encourage more awareness about the various 'ways of knowing' and insights on the dialectics that are needed to relate knowledge that is derived from various sources. The work of Aristotle and the researchers that have further developed his insights can be of great value for EBMgt. Currently, EBMgt is not able to answer the question of how professionals relate various forms of evidence. If this question remains unsolved, EBMgt fails in its ambition to empower professionals in decision-making.

\section{Concluding Remarks}

In the field of business ethics, the relationship between ethics and craftsmanship is currently being discussed with the aim of reorienting practices in business and economics, a necessity that became even more urgent after the financial crisis of 2008. Craftsmanship is a relevant new avenue with which to relate ethics to business. In this article, I have argued that this reorientation can be effective when a relationship is developed between ethics and the role of evidence in professional practices. To enable a reorientation, a behavioural perspective on decision-making can be helpful. Among other things, it helps us to understand the limitations of the perceptions of individuals, organisations and societies in developing evidence. To put it more simply: Behavioural theory helps to be able to grasp the muddy and fuzzy processes of decision-making, a process that Aristotle already struggled with in his day.

Behavioural theorists can also learn something from ethicists. Until now, behavioural theory of the firm has paid relatively little attention to the issue of which perceptions and opinions influence professionals in decision-making, how they reflect upon their own opinions and what is the role of training and professional organisations within these processes. There has also been relatively little focus on the moral aspects of these assumptions, in addition to positions of power in organisations and the influence of the wider environment, even though these elements heavily influence decision-making processes. Finally, there has been scant recognition of the relationship between scientific research and practice, even though a close link was the original aspiration.

I propose that for a reorientation of professionals as 'craftsmen', scholars can build on the foundations laid by behavioural theory of the firm. Insights into the relationship between individual cognition, institutional processes and ethics can then be brought into the equation. We can make these broad concepts more concrete by considering what knowledge, skills and competences decision-makers require in practice, thereby also linking in EBMgt. Reflective capacity is crucial here, and can be concretised by posing questions at the individual, organisational and institutional levels.

Acknowledgements I would like to thank the editors and the two reviewers for all their constructive comments. Also I would like to thank my AUAS-colleagues Eline van der Steen, Marion Smit, Lucy Kerstens, Arjen van den Akker, Willem Baumfalk, Gert de Jong, Huib de Jong en Richard Puyt for their ideas, comments and support.

\section{Compliance with Ethical Standards}

Ethical Approval This article does not contain any studies with human participants performed by the author.

Open Access This article is distributed under the terms of the Creative Commons Attribution 4.0 International License (http://creativeco mmons.org/licenses/by/4.0/), which permits unrestricted use, distribution, and reproduction in any medium, provided you give appropriate credit to the original author(s) and the source, provide a link to the Creative Commons license, and indicate if changes were made.

\section{Appendix 1: Dutch Bankers' Oath.}

I swear/promise within the limits of my role that I perform at any moment in the banking sector: that I will perform my duties with integrity and care; that I will carefully consider all the interests involved in company, i.e. those of the clients, the shareholders, the employees and the society in which the company operates; that in this consideration, I will give paramount importance to the client's interests; that I will comply with the laws, regulations and codes of conduct applicable to me; that I will observe confidentiality in respect of matters entrusted to me; that I will not abuse my knowledge; that I will act in an open and assessable manner and I know my responsibility towards society; that I will endeavour to maintain and promote confidence in the financial sector.

So help me God/This I declare and promise.

Name [signature] * (retrieved from website Nederlandse Vereniging van Banken (Dutch Association of Banks), September 6, 2016, https://www.nvb.nl/.../001840_Future-orien ted\%20Banking.pdf).

\section{References}

Argyris, C., \& SchÓ§n, D. A. (1974). Theory in practice: Increasing professional effectiveness. San Francisco: Jossey-Bass.

Ariely, D. (2009). Predictably irrational, The Hidden Forces that Shape Our Decisions. Harper Collins Publishers, London.

Baba, V. V., \& HakemZadeh, F. (2012). Toward a theory of evidencebased decision making. Management Decision, 50(5), 832-867. 
Bagdasarov, Z., Johnson, J. F., MacDougall, A. E., Steele, L. M., Connelly, S., \& Mumford, M. D. (2016). Mental models and ethical decision making: The mediating role of sense making. Journal of Business Ethics, 138(1), 133-144.

Barker, R. (2010). No, management is not a profession. Harvard Business Review, 88(7-8), 52-60.

Bazerman, M., \& Gino, F. (2012). 'Behavioral Ethics: Toward a Deeper Understanding of Moral Judgment and Dishonesty'. Annual Review of Law and Social Science, 8, 85-104.

Bernstein, R. J. (1971). Praxis and action: Contemporary philosophy of human activity. Philadelphia: University of Pennsylvania Press.

Bernstein, R. J. (2013). Pragmatism, pluralism, and the healing of wounds. In The American Philosophical Association Centennial Series (pp. 601-615). Charlottesville: Philosophy Documentation Center.

Bowen, F. (2007). Corporate social strategy: competing views from two theories of the firm. Journal of Business Ethics, 75(1), 97-113.

Briner, R. B., Denyer, D., \& Rousseau, D. M. (2009). Evidence-based management: concept cleanup time? The Academy of Management Perspectives, 23(4), 19-32.

Brinkmann, J. (2009). Putting ethics on the agenda for real estate agents. Journal of Business Ethics, 88(1), 65-82.

Brinkmann, J., \& Henriksen, A. M. (2008). Vocational ethics as a subspecialty of business ethics-structuring a research and teaching field. Journal of Business Ethics, 81(3), 623-634.

Cohen, M. D. (2007a). Reading Dewey: Reflections on the study of routine. Organization Studies, 28(5), 773-786.

Cohen, M. D. (2007b). Perspective-administrative behavior: Laying the foundations for Cyert and March. Organization Science, 18(3), 503-506.

Cyert, R. M., \& March, J. G. (1963). A behavioral theory of the firm (Vol. 2). Englewood Cliffs: Prentice-Hall.

De Cremer, D., Mayer, D. M., \& Schminke, M. (2010). Guest editors' introduction: On understanding ethical behavior and decision making: A behavioral ethics approach. Business Ethics Quarterly, 20(01), 1-6.

Dewey, J. (1910). How we think. New York: Hrath \& Co.

Dewey, J. (1939). Theory of valuation. In P. Weiss (Ed.), International encyclopedia of unified science. Chicago: University of Chicago Press.

DiMaggio, P. J., \& Powell, W. W. (1983). The iron cage revisited: Institutional isomorphism and collective rationality in organizational fields. American Sociological Review, 48, 147-160.

Eikeland, O. (2008). The ways of Aristotle. Aristotelian phrónêsis, Aristotelian Philosophy of Dialogue, and Action Research. Bern: Peter Lang.

Eikeland, O. (2012). Action research-applied research, intervention research, collaborative research, practitioner research, or praxis research? International Journal of Action Research, 8(1), 9-44.

Eikeland, O., \& Nicolini, D. (2011). Turning practically: broadening the horizon. Journal of Organizational Change Management, 24(2), 164-174.

Feldman, M., \& Worline, M. (2016). The practicality of practice theory. Academy of Management Learning \& Education, 15(2), 304-324.

Fichter, R. (2016), Do the right thing! Developing Ethical Behavior in Financial Institutions. Journal of Business Ethics. https://doi. org/10.1007/s10551-016-3275-7.

Flyvbjerg, B. (2001). Making social science matter: Why social inquiry fails and how it can succeed again. Cambridge: Cambridge University Press.

Fontrodona, J., Sison, A. J. G., \& de Bruin, B. (2013). Editorial introduction: Putting virtues into practice. A challenge for business and organizations. Journal of Business Ethics, 113(4), 563-565.

Gavetti, G. (2012). Perspective-toward a behavioral theory of strategy. Organization Science, 23(1), 267-285.
Gavetti, G., Levinthal, D., \& Ocasio, W. (2007). Perspective-neo-Carnegie: The Carnegie school's past present, and reconstructing for the future. Organization Science, 18(3), 523-536.

Giessner, S., \& Van Quaquebeke, N. (2010). Using a relational models perspective to understand normatively appropriate conduct in ethical leadership. Journal of Business Ethics, 95, 43-55.

Granovetter, M. (1985). Economic action and social structure: the problem of embeddedness. American Journal of Sociology, 91, 481-510.

Hodgkinson, G. (2012). The Politics of Evidence-Based Decision Making. Oxford Handbooks Online. Retrieved 22 Aug. 2014, from http://www.oxfordhandbooks.com/view/, https://doi.org/10.1093/ oxfordhb/9780199763986.001.0001/oxfordhb-9780199763 986-e-23.

Hornung, S. (2012). Beyond "New Scientific Management" Critical Reflections on the Epistemology of Evidence-Based Management. Oxford Handbooks Online. Retrieved 22 Aug. 2014, from http:// www.oxfordhandbooks.com/view/, https://doi.org/10.1093/oxfor dhb/9780199763986.001.0001/oxfordhb-9780199763986-e-22.

Kahneman, D. (2002). Maps of bounded rationality: A perspective on intuitive judgment and choice. Nobel Prize Lecture, 8, 351-401.

Khurana, R. (2010). From higher aims to hired hands: The social transformation of American business schools and the unfulfilled promise of management as a profession. Princeton: Princeton University Press.

Khurana, R., \& Nohria, N. (2008). It's time to make management a true profession. Harvard Business Review, 86(10), 70-77.

Koumakhov, R. (2009). Conventions in Herbert Simon's theory of bounded rationality. Journal of Economic Psychology, 30(3), 293-306.

Koumakhov, R. (2014). Conventionalism, coordination, and mental models: From Poincaré to Simon. Journal of Economic Methodology, 21, 251-272.

MacIntyre, A. (1985). Relativism, power and philosophy. In: Proceedings and addresses of the American Philosophical Association (pp. 5-22). American Philosophical Association.

March, J. G. (1987). Ambiguity and accounting: The elusive link between information and decision making. Accounting, Organizations and Society, 12(2), 153-168.

Martin, K., \& Parmar, B. (2012). Assumptions in decision making scholarship: Implications for business ethics research. Journal of Business Ethics, 105(3), 289-306.

McPherson, D. (2013). Vocational virtue ethics: Prospects for a virtue ethic approach to business. Journal of Business Ethics, 116(2), 283-296.

Mintzberg, H. (2004). Managers, not MBAs: A hard look at the soft practice of managing and management development. Oakland: Berrett-Koehler Publishers.

NBA-VRC. (2014). Visiedocument over het beroep van de Financieel Professional [Vision document regarding the future of the Financial Professional]. Amsterdam: NBA-VRC.

Nielsen, R. P. (2010). Practitioner-based theory building in organizational ethics. Journal of Business Ethics, 93(3), 401-406.

Nielsen, R. P. (2016). Action research as an ethics Praxis method. Journal of Business Ethics, 135, 419-428.

Nussbaum, M. C. (2010). Not for profit: Why democracy needs the humanities. Princeton: Princeton University Press.

Pagan, N. O. (2008). Configuring the moral self: Aristotle and Dewey. Foundations of Science, 13(3), 239-250.

Painter-Morland, M. (2006). Redefining accountability as relational responsiveness. Journal of Business Ethics, 66(1), 89-98.

Purnell, L. S., \& Freeman, R. E. (2012). Stakeholder Theory, Fact/ Value Dichotomy, and the Normative Core: How Wall Street Stops the Ethics Conversation. Journal of Business Ethics, 109(1), 109-116. 
Rousseau, D. M. (2006). Is there such a thing as 'evidence-based management'? Academy of Management Review, 31(2), 256-269.

Ruhe, J., \& Nahser, F. B. (2001). Putting American pragmatism to work in the classroom. Journal of Business Ethics, 34(3), 317-330.

Sandberg, J., \& Pinnington, A. H. (2009). Professional competence as ways of being: An existential ontological perspective. Journal of management studies, 46(7), 1138-1170.

Sandberg, J., \& Tsoukas, H. (2011). Grasping the logic of practice: Theorizing through practical rationality. Academy of Management Review, 36(2), 338-360.

Schein, E. (1973). Professional Education, Report to the Carnegie Commission for the Advancement of Teaching.

Schön, D. A. (1983). The reflective practitioner: How professionals think in action. New York: Basic Books.

Schön, D. A. (1995). The new scholarship requires a new epistemology. Change: The Magazine of Higher Learning, 27(6), 27-34.

Sennett, R. (2008). The craftsman. London: Penguin Books.

Seo, M. G., \& Creed, W. D. (2002). Institutional contradictions, praxis, and institutional change: A dialectical perspective. Academy of Management Review, 27(2), 222-247.

Shotter, J., \& Tsoukas, H. (2014). In search of phronesis: Leadership and the art of judgment. Academy of Management Learning \& Education, 13(2), 224-243.

Simon, H. A. (1965). Administrative decision making. In Public Administration Review (pp. 31-37). New York: Macmillan.

Simon, H. A. (1986). The information processing explanation of Gestalt phenomena. Computers in Human Behavior, 2(4), 241-255.

Simon, H. A. (1996). The sciences of the artificial. Cambridge: MIT Press.

Sonenshein, S. (2007). The role of construction, intuition, and justification in responding to ethical issues at work: The sensemaking-intuition model. Academy of Management Review, 32(4), 1022-1040.

Taylor, S. S., Ladkin, D., \& Statler, M. (2015). Caring orientations: The normative foundations of the craft of management. Journal of Business Ethics, 128(3), 575-584.

Thomson, K., \& Jones, J. (2016). Precarious professionals:(in) Secure identities and moral agency in neocolonial context. Journal of Business Ethics, 146(4), 747-770.

Treviño, L. K., Weaver, G. R., \& Reynolds, S. J. (2006). Behavioral ethics in organizations: A review. Journal of management, 32(6), 951-990.

Tversky, A., \& Kahneman, D. (1974). Judgment under uncertainty: Heuristics and biases. Science, 185(4157), 1124-1131.

Vermeulen, F. (2007). "I shall not remain insignificant": Adding a second loop to matter more. Academy of Management Journal, 50(4), 754-761.

Weick, K. E. (1995). Sensemaking in organizations. Thousand Oaks: Sage.

Weick, K. E. (2016). 60th Anniversary essay constrained comprehending: The experience of organizational inquiry. Administrative Science Quarterly, 61(3), 333-346.

Werhane, P. H. (2008). Mental models, moral imagination and system thinking in the age of globalization. Journal of business ethics, $78(3), 463-474$.

Werhane, P. H., Hartman, L. P., Archer, C., Englehardt, E. E., \& Pritchard, M. S. (2013). Obstacles to ethical decision-making: Mental models, Milgram and the problem of obedience. Cambridge: Cambridge University Press. 